\title{
Professional Linguistic Identity of a Mining Engineer: Formation Levels
}

\author{
Natalia Dolgova ${ }^{1, *}$, Julia Larionova ${ }^{1}$, Inna Gubanova ${ }^{1}$, and Anastasia Shirokolobova ${ }^{1}$ \\ ${ }^{1}$ T. F. Gorbachev Kuzbass State Technical University, Foreign Languages Department, 650000 \\ Kemerovo, 28 Vesennya St., the Russian Federation
}

\begin{abstract}
The paper deals with professional linguistic identity, the study of which is the priority area of cognitive terminology studies. The purpose of the paper is to analyze the development stages of professional linguistic identity of a mining engineer dealing with tailing dams and embankments and failures and accidents on them. The analysis of a mining engineer professional linguistic identity formation was carried out according to the three level system: 1) the level of specialist professional consciousness; 2) the verbal level; 3 ) the motivation and pragmatic level. As the result of this investigation the term system structure was developed, which showed the formation of professional linguistic identity. The final stage of professional linguistic identity formation is the script construction. The analyzed stages highlight that development and activity of professional linguistic identity reflect connections of a person with his/hers professional activity, and peculiarities of the person mentality prescribe priority ways of conceptualization and categorization of the world. The result is professional discourse which demonstrates professional qualities of professional linguistic identity.
\end{abstract}

\section{Introduction}

The successful implementation of cognitive approach to terminology caused the relation of terminological researches to cognitive science, which allowed looking at the term and the term system, at structures of professional knowledge denoting the terms, at professional communication, and at the professional linguistic identity in a new light. We believe that at the moment the most promising areas of cognitive terminology are "the study of special vocabulary performance in different types of discourse (scientific and oral professional discourse), the development of the coherent typology of professional discourses, subdiscourses, genres of professional communication, and the study of professional linguistic identity, and the development of professional linguistic identity typology" [1]. The category of professional linguistic identity (PLI) is one of the main categories of cognitive terminology, and it manifests itself through scientific discourse, reflecting knowledge of the world and estimated attitudes to it [2].

\footnotetext{
*Corresponding author : dolgowanatali@mail.ru
} 


\section{Materials and Methods}

The purpose of this paper is to describe the process of professional linguistic identity formation of a mining engineer, who deals with the construction of tailing dams and dikes. Currently, the hydraulic technology terms are used by specialists in the developed and developing countries, as the term system provides adequate communication of hydraulic technology experts in mining industry; and the university education of future mining engineers should be based on basic knowledge of hydraulic technology and hydraulic technology terminology for the implementation of professional activity in the field of dams' construction and mining.

The first level of analysis of professional linguistic identity includes "identification and establishment of the value and meaning hierarchy (concepts and domains as mental formations, reflecting the structure of special experience) in the world view" [3]. As the result of practical material study (Russian monographs and scientific papers on the construction of tailings dams and their functioning, reference and educational literature, and materials investigating causes of dam accidents), it was found that these technical terms verbalize some basic concepts, each of which is the semantic field: dam type, dam structure, equipment, dam fill type, dam material, minerals, types of dam failure.

These term system concepts can be attributed to the essential ones due to the fact that they reflect the general idea of dam construction; they exhibit component and system interconnections with each other, indicating a set of functional features of tailing dams and mechanisms and provide adequate professional communication of specialists.

Composition of the nominative fields of a scientific concept is the determination and description of linguistic resources complex, nominating the analyzed concept and its individual features. Because of the nominative field heterogeneity there is always a problem of its proper structuring. In structuring the nominative field of the concept sphere all available nominative fields of the allocated concepts were determined, including the nomination of its denotations; the key term-representatives were determined for this purpose - these were lexical units, which showed objectively real process of hydraulic structure construction.

The term-representative of the concept dam type is the term dam because of its frequent use in the analyzed empirical sources. The core of the nominative field to the term dam through synonymous expansion is such terms as: dike, embankment, dike dam, dyke, water storage tank, desilt basin.

The definition studies of terms verbalizing basic concepts revealed the nuclear components and synonymic row. The term dam means "hydraulic structure in the form of embankment, protecting a water zone or a territory from water effects" [4], or "a barrier preventing the water flow or solids (such as soil or snow), or a barrier which partitions a stream flow to flood".

The definitions show that nuclear components of the term "dam" are presented in the following semes: "barrier", "partition/fence", "water or solids", "waters", "flooding". The term "dam" definition analysis demonstrates semantic opposition: on the one hand it is a barrier to prevent water or solids, on the other it is a device for accumulation of large amounts of water. Such opposition of meanings allows suggesting that the term combines various features or functional characteristics; it is a protecting object and a pooling block. Therefore, the terms, including the term-representative "dam" in their structure and having the above features and characteristics, verbalize the concept "dam type". Thus, this concept is characterized by the following conceptual features: "hydrotechnical object", "technical features of an object" and "functional purpose".

Definition analysis shows the semantic structure of the concept "dam type" and reflects the "general idea" of dam construction science, demonstrates the system of components and 
relation between them, designating a set of functional features of the hydraulic structure and mechanisms of its functioning.

The semantics of the terms shows the purpose of erection of the following types of dams:

- embankment dams (bund walls or bulkheads), designed to protect the lowlands in the valleys of large rivers and coastlines from flooding (overflow);

- free flow dams (for regulation of riverbeds);

- connecting dams (for connecting the hydroelectric facilities with banks).

There are the following subjects of construction:

- natural processes (water flow, arranging log jams and hanging dams from debris and ice);

- beavers;

- people.

According to the construction methods there are the following types of dams:

- alluvial dams;

- filling dams;

- explosive dams;

- man made levees (involving building materials: concrete, steel, and so on).

Dams are distinguished according to the type of main material:

- earth dams;

- composite-type rock-fill dams;

- rock-fill dams;

- concrete dams;

- steel dams;

- timber dams.

As for correct usage there are the following types of dams:

- storage dams;

- flush weirs;

- impounding dams (intended to increase the level of upstream water).

Dams are distinguished according to the main load:

- gravity dams;

- buttress dams;

- arched dams;

- gravity-arch dams;

- anti-control dams.

There are the following types of dams according to the construction method:

- rock-fill dams;hydraulic-fill dams;

- by means of directed blast.

Dams are distinguished according to the way of water duty:

- deaf dams (do not allow water overflow through the ridge);

- overflow dams;

- filter dams (water passes through the dam body).

Dams are distinguished according to equipment usage:

- spillway dams;

- flush weirs;

- annicuts.

According to the time period there are the following ones:

- permanent dams;

- temporary dams.

Special characteristics of dams' construction should be taken into account for training engineers-hydrologists; they should know that dams are built only by men, while embankments can be built by water stream, beavers, and people. As for all the other 
parameters (type of the main material, purpose, and so on) these hydrological objects are the same. The scheme of dam construction concept sphere is considered in the paper. There is no doubt that this scheme is the term system outline, which was built over the centuries, and as a result has acquired this structural model. The scheme clearly shows the complexity of term system structure. Thus, based on the main concepts that occupy the central position in this scheme, it is possible to classify all the nominative units of the term system taking into account their reference to a certain phase and process of dam construction (Table 1).

Table 1. Hydro-technical term system.

\begin{tabular}{|c|c|c|}
\hline $\begin{array}{l}\text { Concepts } \\
\text { (I level) }\end{array}$ & $\begin{array}{l}\text { Sub-concepts } \\
\text { (II level) }\end{array}$ & $\begin{array}{l}\text { Sub-subconcepts } \\
\text { (III level) }\end{array}$ \\
\hline \multirow[t]{6}{*}{$\begin{array}{l}\text { Dam type } \\
(44 \text { terms })\end{array}$} & $\begin{array}{l}\text { Filter dam }(5 \\
\text { terms })\end{array}$ & \\
\hline & \multirow[t]{2}{*}{ Dyke (15 terms) } & $\begin{array}{c}\text { Earth -and -rock- fill dam ( } 9 \\
\text { terms) }\end{array}$ \\
\hline & & Ground dam (6 terms) \\
\hline & \multirow{3}{*}{$\begin{array}{l}\text { Over flow dam } \\
\quad(24 \text { terms })\end{array}$} & Arch dam (3 terms) \\
\hline & & Gravity dam (14 terms) \\
\hline & & Counterfort dam ( 1 term) \\
\hline $\begin{array}{c}\text { Mineral } \\
\text { deposits } \\
(30 \text { terms) }\end{array}$ & & \\
\hline \multirow{3}{*}{$\begin{array}{l}\text { Equipment } \\
\text { (130 terms) }\end{array}$} & Filters (40 terms) & \\
\hline & $\begin{array}{l}\text { Spill way (53 } \\
\text { terms) }\end{array}$ & \\
\hline & Pipes (37 terms) & \\
\hline \multicolumn{3}{|l|}{$\begin{array}{c}\text { Dam fill type } \\
(115 \text { terms })\end{array}$} \\
\hline \multirow[t]{6}{*}{$\begin{array}{l}\text { Dam structure } \\
\text { (148 terms) }\end{array}$} & $\begin{array}{c}\text { Dam head (49 } \\
\text { terms) }\end{array}$ & \\
\hline & \multirow{3}{*}{$\begin{array}{l}\text { Dam body ( } 59 \\
\text { terms) }\end{array}$} & Berm (14 terms) \\
\hline & & Diaphragm (17 terms) \\
\hline & & Starter (28 terms) \\
\hline & \multirow{2}{*}{$\begin{array}{l}\text { Dam toe }(40 \\
\text { terms) }\end{array}$} & Slopes (17 terms) \\
\hline & & Fill (23 terms) \\
\hline \multicolumn{3}{|l|}{$\begin{array}{c}\text { Dam_material } \\
\text { (14 terms) }\end{array}$} \\
\hline \multirow{3}{*}{$\begin{array}{l}\text { Types of dam } \\
\text { failure } \\
\text { (79 terms) }\end{array}$} & $\begin{array}{l}\text { Landslides (7 } \\
\text { terms) }\end{array}$ & \\
\hline & $\begin{array}{c}\text { Dam breach }(20 \\
\text { terms) }\end{array}$ & \\
\hline & $\begin{array}{c}\text { Seepages (52 } \\
\text { terms) }\end{array}$ & \\
\hline
\end{tabular}

The second stage of analysis of a mining engineer professional linguistic identity formation is the term system analysis, representing the system of knowledge of a specialist. The term system is heterogeneous by its nature as it is characterized by the interaction of several areas of human knowledge: it includes the terms and definitions of the coal industry term system and minerals extraction and processing (Table 2). Despite the fact that the analyzed term system appeared independently, its further development and operation was 
the result of the interaction of adjacent areas of knowledge, which is undoubtedly reflected in language.

Table 2. The terms borrowed from adjacent areas of knowledge.

\begin{tabular}{|c|c|}
\hline $\begin{array}{c}\text { Adjacent areas } \\
\text { of knowledge }\end{array}$ & Borrowed terms \\
\hline Mining & $\begin{array}{c}\text { mine shaft, mine; ground, soil; straddle, balk; coal slurry; waste } \\
\text { rock; collapse; accident; failure, disaster }\end{array}$ \\
\hline Useful minerals & $\begin{array}{c}\text { coal, gold, silver, zinc, copper, shale, bauxite, gypsum, barite, } \\
\text { limestone, mica, fluorite, bentonite, alluviums, titaniferous iron } \\
\text { ore, potash, vermiculite }\end{array}$ \\
\hline $\begin{array}{c}\text { Minerals } \\
\text { processing }\end{array}$ & $\begin{array}{c}\text { tailings, waste water, debris, solution, scrap, flotation tailings, } \\
\text { slurry, water suspension, pulp, ragged stone }\end{array}$ \\
\hline
\end{tabular}

Table 2 shows that the Russian term system borrowed terms from three adjacent sciences (mining, useful minerals, mineral processing) because basic knowledge of these spheres is widely used in tailing dams construction and operation.

Formation of a professional linguistic identity is always accompanied by the process of creation (searching, selection) of a more adequate term; it is not frequent that as a result of practical activity and technology development a large number of synonyms appear. Scientific text, in addition to technical information, reports cognitive information and linguistic means require this information to be objective. Synonyms present information, elaborating professional linguistic identity ideas of various objects characteristics, phenomena of reality. Synonymous relations occur at junction of several categories, in the area of semantic proximity. As the result of cognitive mechanisms of knowledge generation and perception, including the categorization process (the formation of meaning in the process of cognition, the correlation of new ideas with already existing categories according to certain features), lexicalization (linking concepts with verbal means of expression and consolidation in memory of results, obtained through the categorization process) and actualization (removing the wrong words, meanings and knowledge from memory), the word can not only replace or represent real objects, form associations, but also it can analyze the subject peculiarities, their enter into the system of complex relationships.

The reasons of synonymy creation in terminology are different sources of term formation, as well as determination, ordering and regulation of different signs of the studied objects and phenomena, on the basis of which the concepts were formed; that is the way synonymous terms appear, clarifying the existing concept in further development of the scientific field, in the process of parallel development of one and the same field of knowledge in different countries. There are other reasons of synonyms creation: the ability to refer dual concept - with words and phrases; replacing the information in different languages, which is often associated with specific national micro-term systems; lack of conscious, planned, systematic effort to limit the synonyms growth.

Like many other term systems, Russian term system of dam construction demonstrates such phenomenon as synonymy (Table 3 ). Usually synonymy occurs in the emerging term system that refers to its spontaneous nature of birth and development, but dams' construction terms do not belong to such kind of term system, even though it is constantly developing and evolving.

Table 3. The synonymic row of Russian dam construction term system.

\begin{tabular}{|c|c|}
\hline No & Synonymic terms \\
\hline 1 & 1. Dam. 2. Embankment. 3. Weir. \\
\hline 2 & 1. Bulkhead. 2. Protective dam. \\
\hline
\end{tabular}




\begin{tabular}{|c|c|}
\hline 3 & 1. Banked earth. 2. Stockpile. \\
\hline 4 & 1. Drainage. 2. Drainage pattern. 3. Filter. \\
\hline 5 & 1. Draining trench. 2. Open cut drain. \\
\hline 6 & 1. Pipe. 2. Pipe line. 3. Casing pipe. \\
\hline 7 & 1. Bypass line. 2. Bypass conduit. \\
\hline 8 & 1. Delivery pipe. 2. Standpipe. \\
\hline 9 & 1. Waterpump. 2. Pump. \\
\hline 10 & 1. Outflow. 2. Discharge. 3. Spillage. \\
\hline 11 & 1. Drop. 2. Spillover. 3. Water discharge \\
& equipment. \\
\hline 12 & 1. Runoff. 2. Gulley. 3. Gutterway. \\
\hline 13 & 1. Fill ground. 2. Bund. 3. Filling. \\
\hline 14 & 1. Tailings. 2. Cleaning rejects. \\
\hline 15 & 1. Slime. 2. Pulp. 3. Slurry. \\
\hline 16 & 1. Mud. 2. Floatation tailings. \\
\hline 17 & 1. Rock stone. 2. Crushed rock. \\
\hline 18 & 1. Shrinkage. 2. Solidification cracking. \\
\hline 19 & 1. Dam crush. 2. Dike burst. \\
\hline 20 & 1. Sedimentation. 2. Subsidence. \\
\hline
\end{tabular}

Table 3 represents several examples of synonyms. For example, the following row: $a$ dam - an embankment - a weir. The glossary gives the following definition of the term dam - "this is a hydraulic structure in the form of mound, created to protect the area from floods, sea access channels from shoaling, man-made ponds and streams and also to direct water flow deviation". An embankment is - "a hydraulic structure, which dams up watercourse or a body of water to raise water level. It also serves to concentrate pressure at the site of the construction location and to create a reservoir". A weir is - "a cross water retaining structure made of different materials, dams up the watercourse channel and forming a berm at the bottom of the watercourse in order to reduce the longitudinal slope of the bottom of the streambed of the upper site». These definitions suggest that the nominated objects are hydraulic structures designed for water damming, however, these terms are not absolute synonyms, but complement one another by focusing attention on one or other object property.

There are some other examples of synonymous terms: bulkhead - "a dam to protect the territory and buildings from flooding during high water levels in the watercourse"; dyke "a dam made from soil materials of slope stake and it is constructed to protect lower areas from flooding while sea level is rising". The following definitions show that both constructions are objects to protect the territory and buildings from flooding at high levels of water in the watercourse, so these terms are absolute synonyms.

Another example is this row: drainage - drainage system - filter. Drainage - "is a device for collection and removal of filtered water and groundwater"; drainage system - "is removal and drainage of groundwater, soil drainage by means of special ditches and underground pipes (drains)"; filter - "is a construction, designed to remove suspended solids from water filtration". The definitions of the nominated objects show common and distinctive features, according to which it is possible to speak about partial synonymy. Thus, a common feature of all these terms is that the nominated objects are facilities to remove water, and distinguished features of objects are that all structures, except drainage system, remove water and the drainage is carried out through drains. Differentiation of these terms is not only due to the perceptions of these objects, but rather due to presence of emphasis on distinctive features, which were determined on the basis of individual experience of those who participated in nomination process. 
These examples analysis shows that the main purpose of synonymy is not to create semantic doublets, not to create words that are identical in content, but particular semantic gradation to emphasize certain features in the denoted phenomenon, which are not represented by another language form. Synonyms are used to clarify some aspects of the basic concept. Synonyms-terms always refer to the same concept, but have partial differences in the allocation of certain aspects of the concept. Thus, the difference in semantic similarity causes synonyms creation in any term system.

Synonymy in terminology can be considered as a positive fact, indicating the development of scientific thinking and newly discovered sides of reality in other linguistic means. Scientific world view as a special net of person's perception, estimation affects the division of experience and vision of the situation and events through the prism of language and experience" participates in experiencing the world and sets patterns for interpretation of the perceived object.

The third level of investigation of professional linguistic identity formation consists in motivation and pragmatic level analysis, i.e. in analysis of professional texts. At this stage the structure, which reflects the activity of an engineer, was developed, it was to use such a unit of analysis as a script. The script allows displaying the subject-object relationship, as well as those aspects of the semantic components that demonstrate deep processes of nomination and stereotyped sequence of actions in a given situation. Each script should include the following aspects: topic, or title; typical roles; typical conditions; sequence of scenes and actions defined by the purpose; result.

\section{Results}

The process of dam construction, operation and accidents, described by a script is consistent, and each stage (scene) is represented by a certain conceptual and terminological form.

Title: Construction of tailing dams and methods of accidents elimination.

Typical roles.

Builders: designers, engineers, construction workers, consultants, working staff, operators (key terms: designer, engineer, staff, operator).

Customers: dam owners (key terms: owner, master).

Observers: the monitoring committee on the construction and operation of large dams; officials associated with management, planning, meeting necessary requirements for the project authorization; those who are responsible for the stability of the existing tailing dams (key terms: monitoring commission, officials).

Conditions.

Weirs for tailing dams are constructed to save dam with tails and, if possible, materials extracted from tailings can be used in weirs construction. Dams have very much in common with protective dykes, constructed for water resources conservation. In many cases, dykes are build as reservoirs, especially where there is need to accumulate water, or where storage dam should be filled with water to prevent air pollution (key terms: groin, dam, tailings dam, dyke, reservoir, weir).

Scene 1 . The period of dam design.

There are several factors for the safe design of desilt basins and weirs for tailings. First of all, it is necessary to use modern hydrological methods, choose extra-hard composition of clay and the residual strength parameters. Furthermore, the dam safety, downstream water destruction, as well as the potential of clay soils depression should be analyzed and large and well graded filters and drains for drainage which protects the pipeline must be constructed. 
Storage reservoir should be of an appropriate size to store tails safely during the whole period of water tank operation, since its final volume was appropriate to the amount of fossils excavation (key terms: dam, weir, tailings dams, dikes, hydrological method, clay, flooding, downstream water destruction, graduated filter).

Scene 2. The period of dam construction .

Construction can last many years. With the years conditions and requirements change, therefore a flexible approach should be adopted and necessary changes can be added to the project by (key terms: dam construction, project, flexible approach).

Scene 3. The period of dam operation

Planning and management activities include:

1) planning of lining arrangement;

2) control of dam geometry;

3) repair works;

4) dam state monitoring and measurements operation;

5) responsible workers appointment for the prevention of emergency situations and accidents;

6) staff training (key terms: supply, remedial maintenance, monitoring, staff training, dam configuration, earth works).

Recorded measurements, taken during dam construction, should include:

1) amount and properties of the pulp delivered;

2) levels of dam load, water basin, freeboard;

3) position of the ground surface;

4) sedimentary tail properties;

5) washing liquid flowing from the drainage filters;

6) records of any unforeseen leaks or other problems (key terms: slurry, pulp, water basin, freeboard, earthen surface, tailings, drain filter).

Scene 4. Methods and measures to mitigate accidents risk .

To reduce the risk of accidents, it is necessary to carry out structural improvements of dams, organize ancillary works, and carry out supervision improvement, monitoring and maintenance.

Monitoring should include:

1) regular inspection of a dam and equipment from land and air;

2) examination of all measurements and verification of their accuracy;

3) records and reports of all non-conformities;

4) organization of repair works;

5) close cooperation with designers;

6) close cooperation with the authorities.

Approaches to reduce risk while cleaning can include creation of the inundation maps, deluge wave start calculation for different places and duration, as well as safety systems repairing (key terms: improved monitoring, dam inspection, observation, measurement, dam structure improvement).

Scene 5. Accident .

The movement of the dam restraining boundaries can cause shift that will lead to deformation of the structure of the tail mass, a rapid increase of water pressure in the well and the dilution of the dam, causing even greater pressure on the retaining border. Breakdown of restrictive dam can release the liquefied tails that will flow over huge distances and destroy everything because of heavy weight. Water takes the area around and under the buildings, and liquefied tails can destroy the structure (key terms: shift, landslide, liquefaction, flooding, crack, blowout piping).

Scene 6: Accidents reasons investigation. 
The main causes of accidents on the existing dams are instability of the slope, earthquake and transfusions. For inactive dams typical causes of accidents are earthquake and transfusions (key terms: accident, failure, earthquake, transfusion, slope break).

Scene 7. Methods of emergency containment and reconstruction of dams.

This scene is less relevant in the analyzed material sources, therefore, terms verbalized rehabilitation measures were not identified.

The consequences of accidents are serious damage to the environment, human losses, economic damage (key terms: economic losses, environmental pollution).

This is a fundamental sequence of events and actions that make up the script - the process of construction and operation of hydraulic structures. It is possible to assume that in real world there may be certain nuances in realization of such a script, but the structure and the alternation of scenes do not change, as well as the role of the participants in the process.

\section{Conclusions}

The above steps of an engineer professional linguistic identity formation showed that the process of development and functioning of a professional linguistic identity demonstrates close relationship of a person with his professional activity; his peculiarities of thinking dictate the priority ways of conceptualization and categorization of the world. Analysis of the stages of the engineer professional linguistic identity formation showed that the professional activity offers communication strategies and linguistic resources, as a result, professional discourse is produced, which manifests professional qualities of a linguistic identity. The university training of future engineers should be based on successful communication skills formation, which is impossible without certain basic knowledge of the field of training and terminology.

\section{References}

1. E. I. Golovanova International Congress on Cognitive Linguistics, 11 ( 2012)

2. G. V. Elokhova, Questions of cognitive linguistics, 1 (2016)

3. P. Robinson, N. Ellis, Handbook of Cognitive Linguistics and Second Language Acquisition (LMSP, Routledge, 2008)

4. D. Wijaya, G. Ong, Indonesian Journal of Applied Linguistics, 8(1), 1-10 (2018) DOI: 10.17509/ijal.v8i1.11456 